\title{
Limit Learning With Apos Theory and Maple to Develop Mathematical Communication And Critical Thinking
}

\author{
Retno Marsitin ${ }^{1}$, Nyamik Rahayu Sesanti ${ }^{2}$ \\ Kanjuruhan University \\ Mathematics Education \\ Malang, Indonesia \\ 1'mars_retno@unikama.ac.id \\ ${ }^{2}$ nyamik@unikama.ac.id
}

\begin{abstract}
The objective of the research is to develop limit learning module with APOS theory and maple to develop mathematic communication and critical thinking. This research is a development research with Richey \& Klein design and Dick \& Carey model. The study was conducted at the University of Kanjuruhan Malang on mathematics education students who took the calculus course. This development research produces instructional materials in the form of limit learning modules with the theory of APOS and maple on the limit material. The validation of the module includes material, learning and design. Research trials were conducted on small groups and large groups. The result of the experiment showed the achievement $92,9 \%$ for lecturer observation, $89,3 \%$ for student observation, lecturer response $90 \%$, student response $89,8 \%$, mathematical communication skill $80,3 \%$ and critical thinking $80 \%$. It can be concluded from this study that the learning of limits with APOS theory and maple provide practicality, effective and proper to be used in limit learning so that it can develop mathematical communication and critical thinking.
\end{abstract}

Keywords-Limit, APOS, maple, mathematical communication, critical thinking

\section{INTRODUCTION}

Mathematics cannot be separated from thinking activity. Thinking is a person's mental process that is more than just remembering and understanding [1,2]. University-level of mathematics requires the lecturers to innovate in learning. Mathematics learning has common goals: learn to communicate, learn to reason, learn to solve problems, learn to associate ideas, create positive attitudes toward mathematics [3]. Mathematics learning in college-level requires the students to have the ability to think mathematically, so that students do not just memorize formulas or simply apply a mathematical formula [4]

The mathematical communication skill has an important role in solving mathematical problems. The mathematical communication skill appears when analyzing and assessing the thinking and strategic mathematical of others and using mathematical language to express mathematical ideas appropriately $[3,5,6]$. Mathematical communication is a skill in explaining and expressing mathematical ideas, mathematical symbols, mathematical terms and mathematical notation in written and oral correctly. In addition to mathematical communication, the thinking skill is also very influential in the completion of mathematics. Thinking is one of the must-have skills for a person in understanding mathematics. The thinking skill of someone in this case students appear during the process of learning especially mathematics learning. The process of mathematical thinking in the students appears when students construct their skill in mathematical solutions [7]. One of the thinking skills in solving the problem of mathematics is critical thinking. High critical thinking skills contribute significantly to success in solving problems [8,9].

Mathematical learning that demands the mathematical communication and critical thinking skills, including calculus, especially on the limit material. Many students have difficulties in understanding the limit material. When students are faced with limit issues then the answer or the reasons on the answer is not maximal yet. In addition, students still tend to wait for other students' answers without any thinking process so that the mathematical communication and critical thinking skills has not been maximized. This affects the academic achievement of students whereas $70 \%$ less than 75 . One of efforts to overcome student difficulties is through the process of learning, in accordance with the opinion of $[10,11,12]$ states that learning approach that allows students learning more actively in acquiring knowledge and developing thinking through the presentation of problems with the relevant contexts. One of the very relevant learning is learning by utilizing technology in mathematics, such as by using mathematical application software. There are three things that make the principle of utilization of technology are important: technology can improve the quality of mathematics learning, technology can support learning more effectively and technology can give effect about the mathematic material taught [3,13]. One of the utilization of technology in learning mathematics is by using maple mathematics software application in limit learning. The maple mathematics software able to change the different array of representations such as images, tables, graphs, and symbols that 
allows teachers to present broader mathematical knowledge to students $[14,15]$.

Mathematics learning that relevant to the use of maple mathematics application software is mathematics learning with APOS theory. APOS stands for action, process, object, and schema, reflecting one's understanding of mathematical concepts. The theory of APOS is a constructivist theory of how one learns a mathematical concept, thereby helping in developing the mathematical thinking processes that exist within itself $[16,17]$. [18], results showed that the study of mathematics using APOS approach can develop students' positive attitude toward mathematics and able to get used in mathematical thinking and able to improve students' mathematical ability. [19], results showed that the main result of this study is that the proof ability of students' in the APOS group is significantly better than student in TRAD group, so it is strongly suggested to apply APOS theory in Abstract Algebra course. [20], results showed that APOS theory is a useful framework for examining engineering students' understanding related to loops and nested loops. The results of this study have specific implications for researchers and practitioners when designing programming instruction. In relation to the above explanation, this research has a purpose to develop limit learning module with APOS theory and maple to develop mathematical communication and critical thinking.

\section{A. APOS Theory}

APOS Theory is an approach in learning mathematics at the college level by integrating the use of computers, learning in small groups, and paying attention to mathematical connections and creative thinking to understand a mathematical concept, which includes: actions, processes, objects, and schemes abbreviated as APOS, developed by [18,21]. The definitions of APOS theory are (a) Action is a transformation of mental objects to obtain other mental objects and a person is said to experience an action if the person is focusing his mental processes on the effort to understand a given concept; (b) Process is when an action is repeated, then a reflection of action takes place, thus come into a process phase and a person is said to experience a process of a concept if the thinking is limited to the mathematical idea encountered and characterized by the presence of the ability to perform reflection to the mathematical idea; (c) Object is a person who already has the object conception of a mathematical concept, if he has been able to treat the idea or concept as a cognitive object that includes the ability to act on the object, and provide a reason or explanation of its nature and has been able to deconstruct an object into a process whereby it the natures of the object will be used; (d) Scheme is a schema of a particular mathematical material that is a collection of actions, processes, objects, and other schemes that are connected so that form an interrelated framework within the mind of a person, with scheme indicator that is if the person has the ability to construct examples of a mathematical concept in accordance with the natures of the concept. Accordingly, students are required to have the ability to integrate the use of computers, learning in small groups, mathematics connection and creative thinking to understand a mathematical concept $[18,22]$.

\section{B. Maple}

Maple mathematics software is helpful for someone who looking for a mathematical solution (eg for researchers, mathematics users, professors, or students) easily and quickly without having to stuck in difficulty or complexity of mathematical computing or even the difficulty or complexity of the computer $[14,23]$. Maple mathematics software is expected to assist students in mathematical applications. Computer mathematical media is very necessary because it can improve the development of computer literacy skills, and improve attitudes in learning mathematics [24,25]. Maple mathematics application has several benefits that can be used: a) work on enormous numerical computation; b) do a good symbolic computation; c) solving problems in mathematical form; d) complete the animation for two dimensional and three dimensional graphs. In addition, maple has facilities: a) worksheet-based interface, b) facility for creating documents in various formats; c) facility of programming languages that can write function, package and so on; d) facility of standard mathematical functions, such as trigonometric functions [sin $(\mathrm{x}), \cos (\mathrm{x}), \tan (\mathrm{x})]$, e) facility of hyperbolic trigonometric functions $[\sinh (x), \cosh (x)(t), \tan (x)], f)$ inverse facility of trigonometric functions $[\arcsin (\mathrm{x}), \operatorname{arcos}(\mathrm{x}), \arctan (\mathrm{x})], \mathrm{g})$ other facilities such as exponential function, natural logarithm function $(\ln )$, the logarithm function of base $10(\log 10)$, the function of the square root (sqrt), rounding of the nearest integer (round), the fractions (frac).

\section{Mathematical Communication}

The mathematical communication skill includes the ability to: state a situation into mathematical language, symbols, ideas, and mathematical models; explaining and reading meaningfully, expressing, understanding, interpreting, and evaluating mathematical ideas and mathematical presentation orally, in writing, or visually; listening, discussing, and writing about mathematics; and declares an argument in its own language [2,26]. Mathematical communication has an important role in solving mathematical problems. If someone has the mathematical communication skill he is able to interpret and express mathematical concepts in the process of learning mathematics and able to think in solving mathematical problems. Students greatly need to have mathematical communication skill so that students are able to understand abstract mathematical problems in mathematical models and concepts and complete them carefully and thoroughly.

[27], state that communication is a prerequisite for the development of mathematics, so that mathematics can be developed through the communication of ideas. Mathematical communication is the skill to organize mathematical thoughts, communicate logical ideas clearly and logically to others, analyze and evaluate mathematical thoughts and strategies used by others; and using mathematical language to express ideas appropriately $[3,6]$. Communication has an important role in 
mathematics learning [28]. [26,29,30] argues that a lecturer needs to be an effective communicator and that effective communication components are: appropriate terms, connected conversations, transition cues, emphasis and compatibility between verbal and nonverbal acts.

\section{Critical thinking}

Critical thinking is important because by automatic critical thinking one can solve simple and complex problems in everyday life $[31,32]$. Critical thinking is a non-binding process of thinking or just thinking but thinking followed by problemsolving ability, determining the adequacy of data to solve problems, recognizing data consistency, and determining the conclusions of the data set [33,34]. The critical thinking skill includes: giving a simple explanation; building basic skills; concluding; providing a simple explanation and set up strategies and tactics $[35,36]$. Critical thinking has six cognitive thinking skills in it, namely: interpretation, analysis, evaluation, inference, explaining, and reflection thoroughly [37,38]. Critical thinking as "a skilled and active interpretation and evaluation of observation and communication, information and argumentation" [38]. Critical thinking does not merely solve mathematics problems but requires the ability to think in providing logical reasons and solutions in solving mathematics. Critical thinking can be said the ability of an active thinking process in explaining the problems of mathematics clearly, providing information, reasoning, decision making, reflecting and be able to communicate and giving arguments or reasons in giving problem decisions.

\section{METHOD}

This research is a development research with [39] development design and development model of [40]. Richey and Klein's development designs include: analysis, planning, development, and evaluation. Dick and Carey model includes: identifying learning objectives, conducting learning analysis, learner and environment analysis, formulating specific objectives, developing assessment instruments, developing learning strategies, developing and selecting learning materials, designing and executing formative evaluation (through tests), revising learning materials, and designing and executing summative evaluations (through tests). The limits learning with the theory of APOS and maple developed in the form of modules validated by material validators, learning validators and design validators. Furthermore, small group trials and large group trials were conducted to see the responses of lecturers and students to the module developed. The effectiveness of module implementation is analyzed qualitatively, while the mathematical communication and critical thinking skills are analyzed quantitatively. Development research instruments include: (a) questionnaire used as a questionnaire of student responses and questionnaire for the effectiveness of learning modules developed; (b) observation sheets and student worksheets used for obtaining learning activity data and student activity data during learning process; (c) tests of mathematical communication and critical thinking ability used to analyze students' academic abilities.

\section{RESULT AND DISCUSSION}

The results include several stages with Richey and Klein development design including: analysis, planning, development, and evaluation. In the analysis stage the steps are identifying and analyzing the learning objectives with the results indicate that the teaching materials in the form of module is very necessary for students because the module is very helpful for students to understand the concept of limit material on the calculus. This is in line with the learning competency of limits achieved, the students are able to show the behavior of appreciating the exact definition, able to explore examples, able to ask questions, have adequate knowledge and insight about mathematics and other relevant fields of science, deductive thinking, inductive thinking, logical thinking, critical thinking, analytical thinking and creative thinking. Furthermore, planning stage is to prepare the instrument, designing product specifications and contents structure of the module. The preparation of research instruments include: test of mathematical communication ability, test of critical thinking ability, questionnaires and interview questions.

Development stage involves analyzing and developing the learning component, module validation includes: material validation to know the validity of the material, validation of learning to know validity of learning and validation of product design to know the validity of product design (module), revision of module by revising the validation result, suggestion and input from material team expert and revision of validation result, suggestion and input from instructional expert, module test in small group of students of mathematics education program taking calculus course with limit material, module test in large group. The results of the development include: (a) The validation result of the instrument covering test questions, response questionnaire and observation sheet are valid so that the instrument can be used to obtain data. In addition to instrument validation, validation module also done which includes material by lecturer validator as material expert, learning by the learning expert validator and design by the design expert validator with the result that revisions are required for the material on the sample of question and the question should not create double interpretation, revision for the design that less interesting and then revised. After revision, the validator states that the module is valid so that the module can be used in the research trial. Research trials to obtain student and lecturers' responses toward the limit learning module with APOS theory and maple which include: (a) Small group trial conducted to students of mathematics education program taking calculus course on limit material of 9 students; (b) Large group trials were conducted on mathematics education students who took calculus course on limit material of 30 students. Prior to testing, students were given guidance and instructions regarding the use of limit learning modules with APOS theory and maple. Learning limit with APOS theory and maple in the form of developed modules equipped with a material 
explanation with a simple and easy to understand language and interesting to learn, so that students are able to solve the limit problem well.

Furthermore, in the evaluation stage the researchers evaluate and analyze the effectiveness of developed module. In addition, mathematical communication and critical thinking ability were tested through preliminary tests prior to the research trials, the final test after the trial. The test results were the students' academic achievement data. Description of research results in the following table:

\section{TABLE I. ACHIEVEMENT RESULTS IN THE RESEARCH}

\begin{tabular}{|l|c|c|}
\hline \multirow{2}{*}{\multicolumn{1}{|c|}{ Item }} & \multicolumn{2}{c|}{ Trial Test Score } \\
\cline { 2 - 3 } & Small Group & Large Group \\
\hline Observation of student activities & $71,4 \%$ & $89.3 \%$ \\
\hline Observation of lecturer activity & $78.6 \%$ & $92.9 \%$ \\
\hline Mathematical communication skill & $57.9 \%$ & $80.3 \%$ \\
\hline Critical thinking skill & $57.5 \%$ & $80 \%$ \\
\hline Questionnaire for Students Response & \multicolumn{2}{|c|}{$89,8 \%$} \\
\hline Questionnaire for Lecturers Response & \multicolumn{2}{|c|}{$90 \%$} \\
\hline
\end{tabular}

Limit learning with APOS theory in maple appears on the observation of student and lecturer activity. The result of student activity observation showed that students still need assistance to change and actively engaging in learning and discussion, so that the students seem more ready during the presentation and have the ability to understand their own mathematical concept. This is in accordance [41] opinion that for the presentation stage, each group presents their group work, the group that is not presenting as the timer, gives a warning when the time is nearing and includes time for question and answer or the time to comment or feedback of the presentation. Discussion in the group provides an opportunity for students to interact and argue, thus they get an understanding of the correct mathematical concept according to the problem. This is in accordance with the opinion of [42] that group discussion can improve mutual interaction in mutual listening found by others so they get a higher understanding than before. In addition, in accordance with the [43] opinion which states that learning mathematics not only provide enough concept of theory but also provides examples of solutions in reality by utilizing learning strategies that support maximum learning achievement, so that learning focuses on the concepts and core principles involving students in problem-solving investigations and other meaningful tasks, giving students the opportunity to work autonomously in constructing their own knowledge, and reaching the peak of producing real products. The students' academic ability and courage in the presentation also increased in achievement in the second cycle.

In addition, the results of the students' response questionnaire show that the limit learning module with the theory of APOS and maple obtained a positive response from students and it can be said that the limit learning module in accordance with the needs of students that easy, interesting and useful for students. The result of lecturer questionnaire response by two of mathematics lecturers gets positive response. This is supported by the results of interview of three students with low, medium and high ability indicating that the limit learning module with the theory of APOS and maple in accordance with the needs of students, so it can be said that the limit learning module with the theory of APOS and maple provide practicality, effective and proper to be used. This is in accordance with the opinion of $[44,45,46]$ who stated that there are three theories of teaching based on student activeness and lecturer's perspective in understanding the concept of teaching, that is teaching is transferring knowledge to students, accompanied by the effort to activate students and teaching should enable students with a focus on the learning process that must be really meaningful as well as effective.

The result of mathematical communication ability with score $\geq 75$ get $80,3 \%$ achievement and critical thinking with score $\geq 75$ get $80 \%$ achievement it indicates that there is an increase of achievement obtained by student, in accordance with $[28,47]$, when students are given the opportunity to communicate about mathematics, they engage thinking skills and processes that are crucial in developing mathematical literacy. [48,49] states that students must learn thinking and reasoning skills to reach their fullest potential in today's society. It can be said that the limit learning module with APOS theory and maple can foster mathematical communication and critical thinking of students. This has an impact on the academic achievement of students who have improved very well.

\section{CONCLUSION}

The results of the research and discussion that have been explained can be concluded that: (1) Research development of limit learning module with APOS theory and maple by using Richey and Klein development design with Dick and Carey model. Learning limit with the theory of APOS and maple in the form of developed modules equipped with a material explanation, a simple and easy to understand language and interesting to learn, so that students are able to solve the limit problem well. The results showed that the learning of limit with the theory of APOS and maple in the form of module obtained positive response and in accordance with the needs of the students that is easy, interesting and useful for students, so it can be concluded that the limit learning with APOS theory and maple provide practical, effective and proper to be used in learning; (2) The result of mathematical communication and critical thinking skill indicate that there is the achievement obtained by the student increase so that it can be said that the limit learning module with APOS theory and maple can develop the mathematical communication and critical thinking of students. This affects the academic achievement of students who have improved very well, so it can be concluded that the limit learning module with the theory of APOS and maple can foster mathematical communication and critical thinking of students. Suggestions for lecturers who teach calculus courses should use instructional materials in the form of modules and innovate in learning in order to make the students have better 
mastery of mathematics concept and the academic quality of mathematics students better.

\section{REFERENCES}

[1] B. Manfaat and I. Kurniasih, "PENGARUH EMOTIONAL QUOTIENT (EQ) TERHADAP KREATIVITAS BERPIKIR MATEMATIKA SISWA (STUDI KASUS DI KELAS VIII SMPN 4 KOTA CIREBON)," Eduma, vol. 1, no. 2, pp. 81-89, 2012.

[2] U. Sumarmo, Kemandirian belajar: Apa, mengapa, dan bagaimana dikembangkan Pada peserta didik, vol. 8, no. 1983. 2004, p. 9.

[3] National Council Of Teachers Of Mathematics, "Principles and Standards for School Mathematics," Sch. Sci. Math., vol. 47, no. 8, pp. 868-279, 2000.

[4] R. Marsitin, "Connection and Mathematical Disposition Toward Advanced Mathematical Thinking in Apos Mathematics Learning. 2016 International Conference on Education \& Social Science (UKICESS) Educational and Social Issues in the Changing Asia," 2016, pp. 221-231.

[5] W. Umar, "Membangun Kemampuan Komunikasi Matematis dalam Pembelajaran Matematika," J. Infin., vol. 1, no. 1, pp. 1-9, 2012.

[6] Y. Ramdani, "Pengembangan Instrumen dan Bahan Ajar untuk Meningkatkan Kemampuan Komunikasi, Penalaran, dan Koneksi Matematis dalam Konsep Integral," J. Penelit. Pendidik., vol. 13, no. 1, pp. 4452, 2012.

[7] R. Marsitin, "Koneksi Matematis dan Berpikir Kreatif dalam Pembelajaran Matematika dengan Teori APOS," Al-Khwarizmi J. Pendidik. Mat. dan Ilmu Pengetah. Alam, vol. 5, no. 1, pp. 87-100, 2017.

[8] A. W. Kurniasih, "Penjenjangan Kemampuan Berpikir Kritis dan Identifikasi Tahap Berpikir Kritis Mahasiswa Prodi Pendidikan Matematika FMIPA UNNES dalam Menyelesaikan Masalah Matematika," Disertasi dan Tesis Progr. Pascasarj. UM, vol. 0, no. 0, 2010.

[9] Firdaus, I. Kailani, M. N. bin Bakar, and Bakry, "Developing Critical Thinking Skills of Students in Mathematics Learning," J. Educ. Learn., vol. 9, no. 3, pp. 226-236, 2015.

[10] A. Sutawidjaja and J. Afgani, "Konsep Dasar Pembelajaran Matematika," in Pembelajaran Matematika, 2015, pp. 1-25.

[11] Darmawan, "Penggunaan pembelajaran berbasis masalah dalam meningkatkan kemampuan berpikir kritis siswa pada pembelajaran ips di mi darrusaadah pandeglang," J. Penelit. Pendidik., vol. 11, no. 2, pp. 106-117, 2010.

[12] R. Duval, "A cognitive analysis of problems of comprehension in a learning of mathematics," Educational Studies in Mathematics, vol. 61, no. 1-2. pp. 103-131, 2006.

[13] Sahid, "Pengembangan Media Pembelajaran Berbasis
ICT," Pendidik. Mat. FMIPA UNY, pp. 1-16, 2007.

[14] I. Shingareva and C. Lizárraga-Celaya, Maple and mathematica: A problem solving approach for mathematics. 2007.

[15] T. Stancheva, "Differential equations with MAPLE," AIP Conf. Proc., vol. 946, pp. 176-187, 2007.

[16] D. Brijlall, "High school learners' mental construction during solving optimisation problems in Calculus: a South African case study," South African J. Educ., vol. 33, no. 2, pp. 1-18, 2013.

[17] K. Weller, J. Clark, and E. Dubinsky, "Student performance and attitudes in courses based on APOS Theory and the ACE Teaching Cycle," Res. Coll. Math. Educ., vol. 12, pp. 97-131, 2003.

[18] E. Dubinsky and M. A. Mcdonald, "APOS: A constructivist theory of learning in undergraduate mathematics education research," New ICMI Study Ser., vol. 7, no. 3, pp. 275-282, 2002.

[19] I. Arnawa, B. Kartasasmita, and E. Baskoro, "Applying The APOS Theory to improve students ability to prove in elementary abstract algebra," J. Indones. Math. Soc., vol. 13, no. 1, pp. 133-148, 2007.

[20] I. Cetin, "Students' Understanding of Loops and Nested Loops in Computer Programming: An APOS Theory Perspective," Can. J. Sci. Math. Technol. Educ., vol. 15, no. 2, pp. 155-170, 2015.

[21] E. D. Dubinsky and M. A. Mcdonald, "APOS : A Constructivist Theory of Learning in Undergraduate Mathematics Education Research," in The Teaching and Learning of Mathematics at University Level, 2002, pp. 275-282.

[22] M. Parraguez and A. Oktaç, "Construction of the vector space concept from the viewpoint of APOS theory," Linear Algebra Appl., vol. 432, no. 8, pp. 2112-2124, 2010.

[23] P. Adams, "Introduction to mathematics with Maple," Choice Curr. Rev. Acad. Libr., vol. 43, no. 1, p. 136, 2005.

[24] R. Oktaviyanthi and Y. Supriani, "Utilizing Microsoft Mathematics in Teaching and Learning Calculus," Indones. Math. Soc. J. Math. Educ., vol. 6, no. 1, pp. 63-76, 2015.

[25] A. Kilicman, M. A. Hassan, and S. K. S. Husain, "Teaching and learning using mathematics software 'the new challenge,"' in Procedia - Social and Behavioral Sciences, 2010, vol. 8, pp. 613-619.

[26] S. L. Kline and D. K. Ishii, "Procedural explanations in mathematics writing: A framework for understanding college students' effective communication practices," Writ. Commun., vol. 25, no. 4, pp. 441-461, 2008.

[27] K. Lanani, "Belajar Berkomunikasi dan Komunikasi Untuk Belajar Dalam Pembelajaran Matematika," J. Ilm. Progr. Stud. Mat. STKIP Siliwangi Bandung, vol. 2, no. 1, pp. 13-25, 2013.

[28] D. K. Pugalee, "Using communication to develop students' mathematical literacy," Math. Teach. Middle Sch., vol. 6, no. 5, pp. 296-299, 2001. 
[29] Mutaqin, "Peningkatan kualitas pendidikan di perguruan tinggi dilakukan melalui penyiapan tenaga dosen bermutu secara berkelanjutan," 2009.

[30] T. HANDAYANI, "Membangun Komunikasi Efektif Untuk Meningkatkan Kualitas Dalam Proses Belajar Mengajar," $T A$ 'DIB, vol. XVI, no. 2, 2011.

[31] L. G. Snyder, L. G. Snyder, M. J. Snyder, and M. J. Snyder, "Teaching Critical Thinking and Problem Solving Skills," Delta Pi Epsil. J., vol. L, no. 2, pp. 90100, 2008.

[32] N. L. R. Stedman and B. L. Adams, "Identifying Faculty's Knowledge of Critical Thinking Concepts and Perceptions of Critical Thinking Instruction in Higher Educaiion," NACTA J., vol. 56, no. 2, pp. 9-14, 2012.

[33] A. W. Kurniasih, "Penjenjangan Kemampuan Berpikir Kritis dan Identifikasi Tahap Berpikir Kritis Mahasiswa Prodi Pendidikan Matematika FMIPA UNNES dalam Menyelesaikan Masalah Matematika," Disertasi dan Tesis Progr. Pascasarj. UM, vol. 0, no. 0, 2010.

[34] Y. Ramalisa, "Proses Berpikir Kritis Siswa Sma Tipe Kepribadian Thinking Dalam Memecahkan Masalah Matematika," Edumatica, vol. 3, no. 1, pp. 42-47, 2013.

[35] S. S. Dewanti, "Mengembangkan Kemampuan Berpikir Kritis Mahasiswa Bangsa Melalui Pemecahan Masalah,” Pros. Semin. Nas. Mat., pp. 29-37, 2011.

[36] C. Perkins and E. Murphy, "Identifying and measuring individual engagement in critical thinking in online discussions : An exploratory case study Development of a model," Educ. Technol. Soc., vol. 9, no. 1, pp. 298307, 2006.

[37] P. Griffin, B. McGaw, and E. Care, Assessment and teaching of 21st century skills, vol. 9789400723. 2012.

[38] A. Fisher, "Critical Thinking. An Introduction," Library (Lond)., vol. 44, no. 13, p. 17, 2001.

[39] R. C. Richey, J. D. Klein, and M. W. Tracey, The instructional design knowledge base: theory, research, and practice, vol. 53, no. 9. 2011.

[40] W. Dick, L. Carey, and J. O. Carey, "The Systematic Design of Instruction," Educ. Technol. Res. Dev., vol. 54, pp. 417-420, 2006.

[41] P. Dwi and A. Putra, "Pengembangan Sistem ELearning untuk Meningkatkan Keterampilan Berpikir Kritis Mahasiswa Pendidikan Fisika," J. Fis. Indones., vol. XIX, no. 55, pp. 45-48, 2015.

[42] I. W. Santyasa, "Model-Model Pembelajaran Inovatif," Makalah, pp. 1-16, 2007.

[43] Maria Chong Abdullah, Samsilah Roslan, and Tajularipin Sulaiman, "Strategi Pengajaran Pembelajaran di Institusi Pengajian Tinggi: Satu Anjakan Paradigma," Malaysian Educ. Dean's Counc. J., vol. 8, pp. 101-115, 2011.

[44] P. Ramsden, Learning to Teach in Higher Education, vol. 18. 2003.

[45] J. B. Biggs and C. Tang, Teaching For Quality
Learning At University. 2011.

[46] Z. Amin and K. E. Hoon, "Basics in Medical Education.," World Sci., vol. 3, pp. 29-30, 2003.

[47] F. Viseu and I. B. Oliveira, "Open-ended tasks in the promotion of classroom communication in Mathematics," Int. Electron. J. Elem. Educ., vol. 4, no. 2, pp. 287-300, 2012.

[48] D. Haryani, "Pembelajaran Matematika Dengan Pemecahan Masalah," Pros. Semin. Nas. Penelitian, Pendidik. dan Penerapan MIPA, pp. 121-126, 2011.

[49] R. D. Rudd, "Defining Critical Thinking," Inq. Crit. Think. Across Discip., vol. 26, no. 1, pp. 38-46, 2011. 